\title{
Evaluation of technological innovation competitiveness of Hebei Province
}

\author{
Rufei Zhang ${ }^{1,}$, , Lijun Liu ${ }^{2, b}$ \\ ${ }^{1,2}$ Institute of economic and trade, Shijiazhuang University of Economics, Shijiazhuang, China \\ azhangrufei1982@163.com, b blue800410@126.com
}

Keywords: Technological innovation. Competitiveness evaluation. Hebei province.

\begin{abstract}
Science and technology innovation is important guarantee to achieve the upgrading of industrial structure and the rapid economic development in Hebei Province. This article through the establishment of four science and technology innovation competitiveness evaluation index system of hebei province science and technology innovation competitiveness evaluation analysis, found in 2011 in hebei province science and technology innovation competitiveness ranking 18 in 31 provinces and autonomous regions in the country, Therefore, Hebei should be fully aware of the seriousness of the current situation, develop effective coping strategies in order to raise its level of competitiveness of Hebei Science and Technology Innovation..
\end{abstract}

\section{Introduction}

With the coming of knowledge economy, technology and innovation have been the main impelling forces to the current world economy and development. Western developed countries and international organizations have realized the importance of science and technology innovation

U.S. National Science Foundation (NSF) began to modern science and technology statistics in the 1940s and 1950s, especially the modern R \& D statistics. China is also aware of the importance of technological innovation; the annual support for technological innovation is also increasing. In 2011 the national R\&D spending is 868.701 billion Yuan, accounting for 1.84\% of GDP, a record high. Hebei Province in 2011 R \& D expenditure was 20.134 billion yuan, accounting for the national R \& D expenditure of $2.32 \%, \mathrm{R} \& \mathrm{D}$ expenditures accounted Hebei GDP, $0.82 \%$, is the national R \& D expenditure to GDP of $44.57 \%$, far below the national average. From R \& D expenditure situation, the Science and Technology Innovation outlook is bleak in Hebei province, but the R \& $\mathrm{D}$ expenditure indicators do not fully measure the competitiveness of a region the level of scientific and technological innovation, it is just one of the core indicators. Thus, the paper constructs technological innovation competitiveness evaluation index system; fully and truly reflect the level of competitiveness of Hebei Province scientific and technological innovation, scientific and technological innovation competitiveness of Hebei Province to identify problems, to promote scientific and technological innovation to enhance the competitiveness of Hebei Province to provide a scientific basis.

\section{The construction of evaluation index system of science and technology innovation competitiveness}

In this paper, the reference number of domestic experts and scholars on the basis of the results, follow the practicality, representativeness, comprehensiveness, scientific principles and sensitivity constructed including four two indicators, nine three indicators, 49 detailed indicators four indicators, indicators are as shown in Table 1. 
Table 1 The evaluation index system of Technological innovation competitiveness

\begin{tabular}{|c|c|c|c|}
\hline $\begin{array}{l}\text { aggregative } \\
\text { indicator }\end{array}$ & $\begin{array}{c}\text { Level2 } \\
\text { indicators }\end{array}$ & Level 3 indicators & Detailed indicators \\
\hline \multirow{9}{*}{$\begin{array}{l}\text { Science and } \\
\text { technology } \\
\text { innovation } \\
\text { competitiveness }\end{array}$} & \multirow{3}{*}{$\begin{array}{l}\text { Base of Science } \\
\text { and technology } \\
\text { innovation }\end{array}$} & Human basis & $\begin{array}{l}\text { College degree or above the number per ten thousand } \\
\text { people,The number of college students per one hundred } \\
\text { thousand people,Illiterate population accounts for the } \\
\text { population aged } 15 \text { and above,Science popularization } \\
\text { professionals }\end{array}$ \\
\hline & & Financial base & $\begin{array}{c}\text { Annual science funds raise, } \\
\text { Regional GDP,Fixed assets investment,Assets } \\
\text { expenditure proportion of R\&D expenses within } \\
\text { budget,Industrial enterprises above designated size } \\
\text { assets expenditure proportion of R\&D expenses within } \\
\text { budget, } \\
\text { Regional finance income } \\
\end{array}$ \\
\hline & & $\begin{array}{c}\text { scientific and } \\
\text { technological base }\end{array}$ & $\begin{array}{l}\text { Science and Technology Museum quantity,Popular } \\
\text { science book publishing category,The amount of per } \\
\text { capita public library,Every people has a public library } \\
\text { building area,R \& D Institutions,Internet Users }\end{array}$ \\
\hline & \multirow{2}{*}{$\begin{array}{l}\text { Science and } \\
\text { technology } \\
\text { innovation } \\
\text { investment }\end{array}$} & human input & $\begin{array}{c}\text { Number of R \& D personnel,Number of R \& D } \\
\text { personnel full-time equivalents,R \& D personnel in the } \\
\text { proportion of doctors and masters,Industrial enterprises } \\
\text { above designated size number of R \& D } \\
\text { personnel,High-tech industry R \& D Personnel }\end{array}$ \\
\hline & & $\begin{array}{l}\text { Financial } \\
\text { investment }\end{array}$ & $\begin{array}{l}\text { R \& D expenditure to GDP,Industrial enterprises above } \\
\text { designated size Expenditures for new product } \\
\text { development,Above-scale industrial enterprises R \& D } \\
\text { project funding,High-tech industry Expenditures for } \\
\text { new product development,High-tech industry R \& D } \\
\text { project funding,Research and development institutions } \\
\text { R \& D Expenditures } \\
\end{array}$ \\
\hline & \multirow[t]{2}{*}{$\begin{array}{l}\text { Scientific and } \\
\text { technological } \\
\text { innovation } \\
\text { output }\end{array}$} & $\begin{array}{l}\text { Output of scientific } \\
\text { and technological } \\
\text { achievements }\end{array}$ & $\begin{array}{l}\text { Authorized number of domestic patent } \\
\text { applications,High-tech industry patent } \\
\text { applications,Industrial enterprises above designated size } \\
\text { number of patent applications,The number of scientific } \\
\text { papers published research and development } \\
\text { institutions,The number of published scientific works } \\
\text { research and development institutions, Research and } \\
\text { development institutions and the transfer of ownership } \\
\text { of patent licensing income,Research and development } \\
\text { institutions to form the number of national or industry } \\
\text { standards }\end{array}$ \\
\hline & & $\begin{array}{l}\text { industrialization of } \\
\text { scientific and } \\
\text { technological } \\
\text { achievements }\end{array}$ & $\begin{array}{l}\text { High-tech industrial output value accounted for the } \\
\text { proportion, The number of national industrialization } \\
\text { projects, Technology market turnover contract amount, } \\
\text { New high-tech industry sales accounted for the } \\
\text { proportion of main business income,Industrial } \\
\text { enterprises above designated size accounted for new } \\
\text { product sales revenue from principal operations }\end{array}$ \\
\hline & \multirow{2}{*}{$\begin{array}{l}\text { Science and } \\
\text { technology } \\
\text { innovation and } \\
\text { social benefits }\end{array}$} & $\begin{array}{l}\text { macro-economic } \\
\text { results }\end{array}$ & $\begin{array}{c}\text { Per capita GDP,Expenditure approach GDP rate of } \\
\text { capital formation,Urban residents per capita disposable } \\
\text { income,Energy consumption per unit of GDP,Tertiary } \\
\text { industry output than the first }\end{array}$ \\
\hline & & $\begin{array}{c}\text { The quality of life } \\
\text { benefits }\end{array}$ & $\begin{array}{c}\text { Life garbage treatment rate,Internet } \\
\text { penetration,Telephone penetration rate (including } \\
\text { mobile phones),Broadcasts comprehensive population } \\
\text { coverage,Television comprehensive population } \\
\text { coverage }\end{array}$ \\
\hline
\end{tabular}




\section{Empirical analysis}

Evaluation method. Comprehensive index method is used as the evaluation method, Firstly, using the formula (1) to standardize the data processing, the individual indicator changed within the range of (0-100).Then, using Equation (2) of the right third, and so aggregated to comprehensive evaluation index value of R. Finally, Accordance with the comprehensive evaluation index value $\mathrm{R}$ the size of the country's 31 provinces and autonomous regions to rank comparative analysis.

$$
\begin{aligned}
& r_{i j k}=100 \Phi\left(\frac{x_{i j k l}-\overline{x_{i j k}}}{s_{i j k}}\right) \\
& R=\frac{1}{4} \sum_{i=1}^{4} \sum_{j=1}^{n_{i}} \sum_{k=1}^{n_{j}} r_{i j k}
\end{aligned}
$$

$i=1, \cdots, 4$,represents level 2 indicators;

$j=1, \cdots, n_{i}$,represents level 3 indicators;

$k=1, \cdots, n_{j}$, represents detail indicators.

The results of assessment. In accordance with the previously established technological innovation competitiveness evaluation index system, using 2012 annual "China Statistical Yearbook" and "China Science and Technology Statistical Yearbook," the data provided in Hebei Province in 2011 to evaluate the competitiveness of scientific and technological innovation, ranking results shown in Table 2 .

\begin{tabular}{|c|c|c|c|}
\hline \multicolumn{3}{|c|}{ indicators } & $\begin{array}{c}\text { rankin } \\
\text { g }\end{array}$ \\
\hline \multicolumn{3}{|c|}{ Science and technology innovation competitiveness } & 18 \\
\hline \multicolumn{3}{|r|}{ The base of Science and technology innovation } & 18 \\
\hline & & Human foundation & 26 \\
\hline & & Financial base & 10 \\
\hline & & scientific and technological base & 22 \\
\hline \multicolumn{3}{|c|}{ Science and technology innovation investment } & 17 \\
\hline \multicolumn{3}{|r|}{ human input } & 18 \\
\hline & & Financial investment & 16 \\
\hline \multicolumn{3}{|c|}{ output of Technological innovation } & 27 \\
\hline \multicolumn{3}{|c|}{ Output of scientific and technological achievements } & 20 \\
\hline & & transformation of scientific and technological achievements & 29 \\
\hline \multicolumn{3}{|c|}{ Social benefits of technological innovation } & 16 \\
\hline & & macro-economic results & 25 \\
\hline & & The quality of life benefits & 12 \\
\hline
\end{tabular}

Table 22011 Hebei Science and Technology Innovation Competitiveness Ranking

\section{Conclusions}

Hebei technological innovation competitiveness of the country's 31 provinces and autonomous regions are ranked 18 in 2011, at the middle level. Science and technology innovation base, science and technology innovation investment, innovation of science and technology output and social benefit, science and technology innovation fourlevel 2 indicators ranked 18, 17, 27, and 16. Which output ranked high science and technology innovation, severely limits the hebei science and technology innovation competitiveness level, while the other three secondary indicators are at the middle level. Nine level 3 indicators, ranked 10 financial base, quality of life benefits ranked 12, financial investment ranked no. 16, human investment ranked no. 18, output ranked 20 scientific and technological achievements, science and technology based ranking 22, macro economic efficiency ranking 25, ranked 26 human basis, scientific and technological achievements industrialization 
number 29. The indicators are not ranked higher in the country's 31 provinces and autonomous regions. Based on the above facts, Hebei must understand the current grim situation facing, ranked the most rearward from the scientific and technological achievements industrialization start, staging itemized to improve the situation, and strive to improve in the short term competitiveness of the province's scientific and technological innovation, in order to rapid and healthy development of the province's economy continued to provide a solid guarantee.

\section{References}

[1] Li Meizhi. Henan Science and Technology Innovation Competitiveness Evaluation and Analysis [J]. Science and Technology Management Research, 2012 (17):68-71

[2] Zhang Keying, Huang Ruihua, Zhu Aihui. Variety of evaluation methods in technological innovation evaluation index Analysis [J]. Science and Technology Management Research, 2005 (11):65-67

[3] Zhao Feng, Zhang Chunqiang, Zhang Leping. Hubei Science and Technology innovation evaluation index system design [J]. Science Technology and Industry, 2010 (10):108-119

[4] Chen Li, Zeng Huifen, Huang Zhihua .Technology innovation Competence Evaluation - A Case Study [J]. Science and Technology Management Research, 2012 (12):12-15

[5] Jiang Xin, Yu Xinghou, Luo Jia. Evaluation of China's Scientific and Technological Innovation Capability[J]. Technoeconomics \& Management Research, 2010(4):41-45 